and of uniformity of quality may be attained for these important products. It is published with the object of ascertaining how the various specifications will work out in practice, and thus it is advisable that interested manufacturers, horticultural advisers, and large users will give it the attention it deserves. The Council of the Association of Applied Biologists has consented to the paper being reprinted for sale, the price being $2 s$. post free; it is obtainable from the author (Research Station, Long Ashton, Bristol).

\section{International Congress of Mining, Metallurgy and Applied Geology}

THE seventh International Congress of Mining, Metallurgy and Applied Geology was opened at the Sorbonne, Paris, on October 20, and will continue until October 26. The President of the Republic, M. Lebrun, was present at the inaugural session. Sir Robert Hadfield, the delegate of the Iron and Steel Institute, presented to M. Lebrun a copy of the picture in the Bodleian Library, Oxford, depicting Roger Bacon presenting a book to the Chancellor of the University of Paris. Sir Robert also presented a miniature knife of steel made by Michael Faraday during the years 1819-24 while he was residing at the Royal Institution. The steel contains 0.74 per cent platinum. The weight of the blade is onehundredth of an ounce, and that of the complete knife, one-twentieth of an ounce. Sir Robert suggested that the knife should be handed either to Dr. Leon Guillet, head of the Ecole Centrale des Arts et Manufactures, or to the Ecole des Mines.

\section{Pasteur Institute of India, Kasauli}

In the thirty-third annual report for 1933 of the Kasauli Pasteur Institute, the Director, Lieut.-Col. Shortt, gives an account of the work of the Institute for 1933. The total number of patients attending the Institute and its various centres was 19,524, an increase of 4,406 as compared with the previous year. Such a large number of patients indicates the widespread threat of rabies in India. The vaccine used was carbolised 5 per cent Paris sheep vaccine, and three out of every four cases with face bites received antirabic serum in addition, as this appears to improve the results obtained. Deducting some 2,000 cases that did not complete the treatment, and 1,446 cases whom it was considered did not require treatment, there were 1,356 Europeans and 14,582 natives treated. There were no deaths among the Europeans, and 83 deaths among the natives, a combined percentage death-rate of only $0 \cdot 52$.

\section{Australian Statistics}

ThE Official Year Book of the Commonwealth of Australia for 1934 (Commonwealth Bureau of Census and Statistics. 5s.) gives as usual an exhaustive summary of all aspects of Australian life and activity. The call of economy still hampers the editor in carrying out all his projects, but he has achieved great success in presenting information in forms that are useful to economists and others. Many details of the census of 1933 are incorporated. An appendix gives a summary of the chief events in connexion with the financial erisis that began in Australia in 1929 .

\section{Craftsmanship in Scientific Instruments}

The Physical Society announces that the seventh annual craftsmanship and draughtsmanship competition will be held as usual in conjunetion with its annual exhibition of scientific instruments and apparatus in January next. Competitors must be in the regular employ of a firm or institution which will be exhibiting or has exhibited at least once during the previous three years, and has been invited by the organising committee to enter its employees for the competition.

\section{Chinese Medical Association}

THE third general meeting of the Chinese Medical Association, the official medical association of China, will be held on November 1-8. This association is the successor to the China Medical Missionary Association organised in 1886. The 1935 meeting will be held at the Canton Hospital, Canton, China, because it was here that Dr. Peter Parker introduced Western medicine into China one hundred years ago. $\mathrm{He}$ was also the world's first regularly appointed medical missionary. A centennial "History of the Hospital" is now in the press (Kelly and Walsh, Shanghai). Besides the regular scientific sessions of the conference, November 2 will be devoted to the centenary celebrations. The new Canton Hospital will be formally opened, and the foundation stone will be laid for the new medical school building. The money for the latter has been obtained by a special grant from the Central Executive of the National Government of China.

\section{New Secretary of the Institution of Naval Architects}

MR. G. V. Boys has been appointed secretary of the Institution of Naval Architects, in succession to $\mathrm{Mr}$. R. W. Dana, who will retire at the close of this year, after thirty-four years of service as secretary. Mr. Boys, who is a son of Sir Charles Vernon Boys, is a graduate of Trinity College, Cambridge (Mathematical Tripos, Pt. 1, and Mechanical Science Tripos). $\mathrm{He}$ is an associate-member of the Institutions of Mechanical and Electrical Engineers, and was for some years a demonstrator in mathematics and mechanics at the Imperial College of Science and Technology; previous to this he was one of the founders of the University of Cambridge Engineering Society. For the past fourteen years he has been on the staff of Messrs. Kennedy and Donkin (consulting engineers).

\section{Royal College of Physicians}

The annual Harveian Oration was delivered on October 18 at the Royal College of Physicians by Sir Henry Dale, director of the National Institute for Medical Research, whose subject was "Some Epochs in Medical Research". The substance of the lecture is printed on p. 690 of this issue. The president of the Royal College of Physicians, Lord 
Dawson of Penn, afterwards presented the Baly Gold Medal to Dr. F. H. A. Marshall and the BissetHawkins Gold Medal to Sir George Newman, lately Chief Medical Officer of the Ministry of Health. The Baly Medal is awarded annually for distinction achieved in the science of physiology. The BissetHawkins Medal is awarded triennially for "such work in advancing sanitary science or in promoting public health as in the opinion of the College deserves special recognition".

\section{Care of Cripples and Invalids}

A JorNT conference of the Invalid Children's Aid Association and the Central Council for the Care of Cripples will be held on November 7-8 at the Drapers' Hall, Throgmorton Street, London, E.C. The opening address will be given by the Minister of Health, Sir Kingsley Wood. The subjects for discussion will be : (1) infectious diseases and their after-effects; immunisation and other preventive measures ; $(2)$ the problem of physical handicap in modern life ; (3) the after-effects of accidents; rehabilitation. Visits will also be paid to various homes and hospitals. The Conference fee, including the report of the proceedings, is 7s. 6d., and should be sent to Miss Wynne (Invalid Children's Aid Association) or Miss Nangle (Central Council for the Care of Cripples), Carnegie House, 117 Piccadilly, W.1, from whom further information may be obtained.

\section{Announcements}

SIR ALBERT Howard, formerly director of the Institute of Plant Industry, Indore, will deliver a lecture entitled "The Manufacture of Humus by the Indore Process", before the Royal Society of Arts on November 13 at 8 p.m.

Prof. Hermann Levy will deliver the Sidney Ball lecture in the University of Oxford on October 29 at 5 p.m. He will take as his subject "The New Aspects of Industrial Combination" and the lecture will be given in the Examination Schools, Oxford.

The Masters Memorial Lectures of the Royal Horticultural Society will be delivered in the lecture room of the Society's new hall in Greycoat Street, Westminster, on November 5 and November 26, at 3.30 p.m., by Sir William Wright Smith, on "Problems connected with the Classification of Plants". Sir Arthur Hill and Sir Daniel Hall have consented to take the chair on these occasions.

Prof. Gregorio Maranón, president of the Spanish Academy of Medicine, has recently been elected president of the Hispano-Belgian scientific entente committee.

Dr. Fritz Lenz, professor of racial hygiene, University of Berlin, has been awarded the Josef Schneider medal by the medical faculty of the University of Würzburg.

A commitTeE has been formed for the erection of a monument at La Ciotat, by the sculptor Paul Gondard of Marseilles, to the brothers Louis and
Auguste Lumière, who were the first to exhibit cinematograph films in September 1895.

ON the occasion of the fiftieth anniversary of the first inoculation for rabies on July 20, a bust of Pasteur was unveiled at Havana in a square to which his name had been given, on the initiative of the academy of Sciences of Havana, in conjunction with the Franco-American Committee of Paris.

Prof. Wilhelm Haberling, of the Düsseldorf Academy of Medicine and joint editor of Mitteilungen zur Geschichte der Medizin, der Naturwissenschaften und der Technik, has recently been awarded the Sudhoff medal by the German Society of the History of Medicine for his eminent services to the study of the history of medicine.

VICTOR Cousin in 1848 described at length a MS. of the Abbey of Corbie now in the Municipal Library of Amiens, which contained a number of treatises by Roger Bacon, written while he was teaching in the University of Paris. Under the title "Opera Hactenus Inedita Rogeri Baconi", the Oxford University Press is publishing shortly the last-the thirteenth-of a series of fasciculi, completing the publication of these treatises, which represent the teaching of the Faculty of Arts in the first half of the thirteenth century. The editors are Mr. Robert Steele and the Rev. Père F. M. Delorme.

The Royal Commission for the Exhibition of 1851 has re-issued its list of whole-time awards for scientific research, other than professorships, offered by public and private bodies in Great Britain and Northern Ireland. The list does not include awards of value less than $£ 150$ a year, neither does it include awards offered by universities and scientific societies exclusively for the benefit of their own members. The list, which brings together in convenient form a good deal of useful information, ean be obtained from the Secretary of the Commission, l Lowther Gardens, Fxhibition Road, London, S.W.7, price $6 d$.

Applications are invited for the following appointments, on or before the dates mentioned :

A senior assistant to the principal (also to teach mechanical engineering) in the Barrow-in-Furness Technical College-The Director of Education, Town Hall, Barrow-in-Furness (Nov. 4).

An assistant (III) at the Fuel Research Station, East Greenwich and a junior scientific officer at the Chemical Research Laboratory, Teddington-The Establishment Officer, Department of Scientific and Industrial Research, 16 Old Queen Streot, S.W.1 (Nov. 5).

A senior lecturer in mathematics, and lecturers in mechanical and civil engineering in the Lester School and Institute, Shanghai-The Lester Trust, c/o Messrs. Viney, Price and Goodyear, Empire House, St. Martin's-le-Grand, London, E.C.1 (Nov. 30).

A lecturer in mechanical and civil engineering in the Rotherham College of Technology and Art-The Director of Education, Education Offices, Rotherham. 